\title{
KEPENARIAN GULU DALAM TARI SRIMPI LUDIRAMADU GAYA SURAKARTA
}

\author{
Aqueenes Forsa Putri Setiawan \\ Institut Seni Indonesia (ISI) Surakarta \\ Jalan Ki Hadjar Dewantara No.19, Kentingan, Jebres, Surakarta 57126 \\ Dwi Rahmani \\ Institut Seni Indonesia (ISI) Surakarta
}

\begin{abstract}
Essay of this artwork present an analysis dizziness of Gulu's in a Srimpi Ludiramadu dance Surakarta sytle covers problem 1). How was the dizziness of Gulu's in the Srimpi Ludiramadu dance?, 2). How does the garap fillings and shapes of Srimpi Ludiramadu dance the dizziness of the Gulu's?, 3). How was Gulu's role in Srimpi Ludiramadu dance?. The three issues are discussed of the normatical concept of the Javanese Hasta Sawanda and the consept of garap fillings and shapes. The methods of art were conducted through library studies, observation, and interviews.

Research has shown that the dizziness Gulu's in a Srimpi Ludiramadu dance is required a process whish is countinue and intensive. Dancing a group dance must be supported by personal and group consciousness. The dizziness of the Gulu's on this Srimpi Ludiramadu was taste of mrabu, kenes, and meneb supported with makeup and karawitan to keep up the impression of grace.
\end{abstract}

Keywords: dizziness, work, Srimpi Ludiramadu.

\section{PENDAHULUAN}

Kepenarian merupakan

kemampuan seorang penari dalam menarikan atau menyajikan sebuah tari dengan bekal yang dimilikinya. Maka untuk menjadi penari yang baik adalah penari yang bisa menarikan tari dengan memunculkan apapun karakter tari yang ditarikan. Bukan menjadi pribadi yang menarikan tetapi menjadi sosok karakter tokoh dalam tari yang dibawakan, sehingga masing-masing penari bebas untuk menginterpretasikan menurut daya tangkap mereka terhadap fenomena tarinya. Hal ini yang nantinya akan memunculkan wiled yang beragam.

Wiled merupakan salah satu konsep tari Jawa dalam Hasta Sawanda. Wiled adalah tehnik gerak kreatif seorang penari berwujud variasi gerak yang khas.

Kesadaran dari seorang penari terhadap dirinya sendiri diperlukan sehingga ketika mereka dituntut untuk menarikan sebuah tari mereka sudah bisa menarikannya sesuai dengan karep dari tari, kebutuhan serta ketubuhan dari 
masing-masing penari. Setiap penari memiliki gandar yang berbeda baik tinggi badan maupun bentuk tubuh. Perbedaan gandar ini akan berpengaruh terhadap pemilihan bentuk dan tehnik yang digunakan dalam menari agar tetap terlihat patut dengan ketubuhan masingmasing penari. Oleh sebab itu, antara penari yang bertubuh tinggi besar dengan yang bertubuh kecil pasti memiliki perbedaan, misalnya terhadap bentuk adeg, tangan, serta tolehan.

Penari dikatakan mumpuni apabila mampu menguasai wiraga, wirama, dan wirasa. Wiraga adalah keterampilan tubuh seorang penari dengan geraknya, jika dikaitkan dengan Hasta Sawanda meliputi unsur pacak, pancat, dan luwes. Wirama adalah keterampilan penari dalam penguasaan akan irama dan gendhing dalam tari. Wirasa adalah keterampilan seorang penari dalam penghayatan serta penjiwaan sebuah tari. Jika dikaitkan dengan konsep Hasta Sawanda mencakup penguasaan ulat, lulut, dan wiled (Dwi Maryani, 2007: 31-33). Hasta Sawanda adalah salah satu konsep normatif tari Jawa gaya Surakarta. Konsep Hasta Sawanda yaitu delapan ketentuan dasar yang terdiri dari pacak, pancat, ulat, lulut, wiled, luwes, irama, dan gendhing.

Lahir dan tumbuh berkembang di lingkungan keluarga pencinta seni merupakan pengalaman yang sangat membanggakan. Peran serta orang tua serta lingkungan dalam mengenalkan kesenian sejak dini dirasa mampu menumbuhkan minat berlebih terhadap kesenian khususnya seni tari. Motivasi dari keluarga terdekat dan kesadaran akan bakat yang dimiliki menjadikan suatu dorongan hingga muncul ketertarikan bagi penulis dalam memperdalam pengetahuan seni. Secara tidak langsung hal inilah yang mendorong untuk terjun secara langsung di dalam dunia kesenian seni tari. Kemudian dipilih Institut Seni Indonesia Surakarta sebagai sarana dan prasarana mendalami bakat tari yang dimiliki. Sejak itulah mulai mengenal beberapa genre tari. Salah satunya genre Bedhaya/Srimpi.

Srimpi merupakan salah satu genre tari tradisi yang lahir di dalam tembok keraton dan memiliki kualitas gerak putri. Tari ini muncul pada akhir abad ke-17, atau tahun 1601 Masehi-1700 Masehi berdasarkan sumber pada "Kamus Istilah Tari dan Karawitan Jawa" koleksi perpustakaan ISI Surakarta. Pada buku Serat Sastramiruda yang ditulis oleh alm. Kangjeng Pangeran Arya Kusumadilaga atau yang dikenal dengan Kangjeng Pangeran Kusumadilaga Tinjomaya yang ditulis kembali oleh R. Ng. Pradjapangrawit dalam Serat Wedhapradangga menyampaikan bahwa:

Prabu Suryawisesa, nata ing Janggala, anganggit beksa dhadhap, lawung lan sapapadhane, ginawe ajaring prang, tinabuhan gendhing warna-warna. Sarta prameswari nata Dewi Candrakirana anganggit beksane badhaya lan sarimpi, tinabuhan gamelan raras surendra, sinangkalan Katon Beksa Putrining Nata 1263 (Serat Sastramiruda, dalam Pradjapangrawit, 1990: 112).

\section{Terjemahan:}

Prabu Suryawisesa, raja di Janggala, menciptakan tari dhadhap, lawung dan serupa lainnya, digunakan 
untuk belajar perang, diiringi gending bermacam-macam, serta permaisurinya yaitu Dewi Candrakirana menciptakan tari bedhaya dan srimpi, diiringi gamelan laras slendro, sengkala Katon Beksa Putrining Nata 1263.

Tari Srimpi merupakan sebuah bentuk koreografi kelompok yang ditarikan oleh empat orang penari putri. Keempat penari putri ini memiliki peran masing-masing yaitu Batak, Gulu, Dhadha, dan Buncit. Jumlah empat penari pada tari srimpi dapat diartikan sebagai simbol makrokosmos dan mikrokosmos kehidupan manusia. Simbol makrokosmos yaitu empat unsur yang ada di jagad raya meliputi grama (api), angin (udara), toya (air), dan bumi (tanah). Selain itu juga ditandai dengan keempat penjuru arah mata angin (utara, selatan, timur, dan barat). Sedangkan simbol mikrokosmos kehidupan dari manusia yaitu empat hawa nafsu yang dimiliki manusia meliputi nafsu amarah, nafsu aluamah (rakus), nafsu supiyah (seks), dan nafsu mutmainah (kebaikan). (Dewan Ahli Yayasan Siswa Among Beksa, 1981:21).

Tari Srimpi Ludiramadu diciptakan oleh Sri Susuhunan Paku Buwana V yang pada saat itu masih bergelar Adipati Anom III. Ia merupakan sosok yang gemar dalam kesenian. Tertulis dalam "Serat Wedhapradangga" sebagai berikut:

Jumeneng dalem nata, Ingkang Sinuhun Kanjeng Susuhunan Paku Bhuwana Ingkang kaping $V$, misuwuring asma Ingkang Sinuhun Sugih, ing Surakarta Adiningrat.... Ingkang sinuhun wau wiwit kala dereng jumeneng nata sampun kathah iyasan-iyasan utawi anggitan dalem. Langkung-langkung bab gendhing Jawi, gendhing alus, gendhing prenes, gendhing gecul.... Lajeng kagungan karsa amiwiti iyasa lelangen dalem beksa wanita, mirip beksa laguning badhaya, kawewahan wileding ukelipun. Katindakaken para kenya cacah sekawan, pinilihan ingkang dedeg pangadegipun sami pasariran ngronje, parigel ing solah. Inggih punika ingkang lajeng winastan lelangen dalem Sarimpi.

Terjemahan:

Bertahtanya raja yaitu, Sinuhun Kanjeng Susuhunan Paku Buwana yang ke $\mathrm{V}$, terkenal dengan nama Sinuhun Sugih, di Surakarta Adiningrat... Sang sinuhun tadi sejak sebelum bertahta menjadi raja sudah banyak karya-karya atau ciptaannya. Lebih-lebih tentang gending Jawa, gending alus, gending prenes, gending gecul... Kemudian mempunyai keinginan mengawali menciptakan tari wanita, mirip tari lagu bedhaya, dengan perubahan wiled ukelnya. Dilakukan para putri berjumlah empat, pilihan yang bentuk posturnya sama berwajah oval, pintar dalam menari. Ya ini yang kemudian dinamakan tari srimpi.

Pada awal kehadirannya tahun 1700-an tari Srimpi hanya mampu dinikmati oleh kaum bangsawan di dalam tembok keraton. Kemudian mulai tahun 1940-an tari Srimpi dan Bedhaya mulai berkembang di luar tembok keraton dan 
tumbuh menjadi tari gaya Surakarta didukung dengan munculnya beberapa pusat kesenian pada tahun 1950 seperti Himpunan Budaya Surakarta (HBS), dan Sekolah Konservatori Karawitan Indonesia yang kemudian disusul munculnya beberapa konservatori lain seperti ASKI dan PKJT pada tahun 1980-an (Widyastutieningrum, 2012: 25).

Minimnya dokumentasi maupun penulisan tari pada masa itu mendorong para empu tari untuk mengadakan sebuah kegiatan revitalisasi berupa rekontruksi, reinterpretasi sebagai upaya dalam melestarikan dan mendukung kehadiran tari tradisi ini. Kegiatan revitaslisasi dilakukan terhadap beberapa tari tradisi seperti Bedhaya dan Srimpi. Salah satunya Srimpi Ludiramadu yang direkonstruksi oleh Agus Tasman pada tahun 1977 (Widyastutieningrum, 2012: 29).

Kegiatan revitalisasi dilakukan guna mempermudah dalam menghayati tari Srimpi yang awalnya berdurasi kurang lebih 1 jam dipadatkan menjadi kisaran 18 menit dengan mengurangi pengulangan sekaran dan gending tanpa menghilangkan atau mengurangi nilai yang ada. Pemadatan ini mengacu pada konsep padat yang dikemukan oleh Rustopo bahwa:

Pemadatan atau konsep "padate pada prinsipnya adalah penggarapan seni tari yang didasarkan atas konsep kemungguhan, yaitu keselarasan atau keserasian atau ketepatan kesatuan wujud antara bentuk, lahir, dan isi atau nilai yang diungkapkan (Rustopo, 2001:159).

Kehidupan tari dari masa ke masa mengalami perubahan dan perkembangan. Perubahan sendiri dapat mengarah ke hal yang lebih baik maupun tidak, sedangkan perkembangan lebih mengarah menjadi lebih baik. Perubahan dan perkembangan ini dipengaruhi oleh beberapa aspek kehidupan antara lain masyarakat, lingkungan, jaman dan kehadiran tari itu sendiri. Meningkatnya jumlah lembaga pendidikan baik formal maupun non formal seperti sanggarsanggar tari, meningkatnya jumlah penari, serta munculnya koreografer tari tradisi seperti Didik Bambang Wahyudi, Wasi Bantolo, Ali Marsudi, serta Rury Nostalgia yang merupakan putri dari maestro tari tradisi Surakarta Retno Maruti dan Arcadius Sentot Sudiharto.

Munculnya tari-tari kreasi

nusantara maupun tari non tradisi nusantara sedikit-sedikit mulai melunturkan pemahaman kita terhadap tari tradisi. Terlebih nilai tinggi yang terkandung pada tari Srimpi yang dirasa sulit untuk dihayati. Nilai tradisi yang terkandung dalam tari, konsep tari serta kualitas tari yang sudah diakui, memunculkan sebuah tantangan tersendiri. Pemahaman serta penghayatan nilai dan isi yang terkandung dalam tari tradisi diperlukan agar kita mampu menangkap nilai-nilai di dalamnya. Agus Tasman dalam buku "Perkembangan Tari di Indonesia (Sebuah Pengahayatan dan Pengamalan Pancasila)" mengungkapkan bahwa:

Permasalahan bagaimana agar kita mampu menangkap isi dan nilai-nilai luhur yang tinggi, yang bermutu, dan semua itu dalam arti sebagai ciri dan wujud kepribadian kita sendiri... Dari sanalah akan tumbuh sikap memiliki serta rasa kehormatan diri. (1987: 8).

Tafsir yang sublim menuntut kita mempelajari secara mendetail dari 
beberapa disiplin ilmu. Selain itu tari ini merupakan salah satu bentuk tari dengan koreografi kelompok yang tidak memunculkan penokohan tertentu sehingga keempat penari dituntut untuk mampu membawakan rasa yang sama. Komposisi kelompok sangatlah mengutamakan keutuhan atau keseluruhan masing-masing kemampuan penari. Karakter yang berbeda dituntut untuk mampu mengontrol ego masingmasing, melatih kesabaran, dan saling membangun interaksi yang baik. Oleh sebab itu, Definisi sublim menurut Kamus Besar Bahasa Indonesia adalah 1. v menampakan keindahan dalam bentuknya yang tertinggi; amat indah; mulia; utama. 2. $n$ perubahan zat padat menjadi uap. Dengan menguasai tari ini diharapkan ketubuhan serta batiniah seorang penari benar-benar terolah.

Pengalaman mengikuti pembelajaran tari tradisi gaya Surakarta khususnya genre Srimpi baik formal maupun non formal yang telah diikuti selama ini menumbuhkan ketertarikan yang lebih terhadap tari dengan genre tersebut. Beragam tari srimpi yang sudah dipelajari hingga saat ini dirasa mampu memberikan dampak peningkatan ketubuhan. Melihat fenomena-fenomena tersebut di atas muncullah ketertarikan terhadap tari tradisi gaya Surakarta yaitu tari Srimpi Ludiramadu yang dilihat dapat digunakan sebagai sarana dalam peningkatan kualitas dasar kepenarian serta upaya memahami dan menghayati nilai dalam tari tradisi. Garap suasana gending, gerak, dan pola lantai yang menarik memunculkan keinginan kuat untuk menarikannya. Selain itu, tarian ini tidak diajarkan secara langsung dalam perkuliahan repertoar tari tradisi Gaya Surakarta Putri sehingga terdapat tantangan tersendiri dalam melakukan proses pendalaman dan pemahaman secara mandiri.

\section{Gagasan}

Kehidupan tari tidak akan pernah lepas dari kehadiran seorang koreografer dan penari. Penari sebagai media ungkap keindahan memiliki peran yang sangat penting. Selain bakat dari seorang penari itu sendiri, juga harus diimbangi dengan kemauan dari dalam diri. Menampilkan tarian yang baik harus dengan melakukan proses latihan secara intensif dan countinue (berulang-ulang dan bertahap). Memperbanyak melakukan riset ketubuhan dalam pencarian tehnik gerak yang sesuai dengan tubuh dari masingmasing penari. Selain itu memotivasi diri sendiri bahwa menari bukan hanya menampilkan keindahan bentuk tubuh tetapi menari adalah sarana meditasi, berdoa kepada Tuhan dan juga sebagai sarana mengungkapkan ide gagasan dari seorang koreografer. Sal Murgiyanto dalam bukunya "Koreografi" menyebutkan bahwa seorang penari harus memiliki halhal berikut antara lain, ketrampilan gerak, penghayatan dan kemampuan dramatik, rasa irama, rasa ruang, daya ingat, kemampuan kreatif (1992: 4-5).

Pendapat tersebut apabila ditarik dalam konsep tari Jawa mencakup kemampuan penguasaan konsep tri wira yang terdiri dari wiraga, wirama, dan wirasa. Buku "Aspek-Aspek Dasar Koreografi Kelompok" oleh Sumandiyo Hadi menjelaskan pengertian koreografi kelompok sebagai berikut: 
Koreografi kelompok adalah komposisi yang ditarikan sebagai lebih dari satu penari atau bukan tarian tunggal (solo dance), sehingga dapat diartikan duet (dua penari), trio (tiga penari), kuartet (empat penari), dan seterusnya (2003: 2).

Pengertian tersebut dapat dikatakan bahwa koreografi tari Srimpi Ludiramadu masuk dalam kategori sebagai bentuk koreografi kelompok besar. Ketika menarikan sebuah komposisi tari kelompok seperti tari srimpi terdapat beberapa aspek yang harus dipertimbangkan, di antaranya pada pemilihan kualitas penari pendukung serta postur tubuh penari yang dibutuhkan. Masing-masing penari harus ada sebuah interaksi yang dibangun sehingga muncul keutuhan kerjasama dalam mewujudkan sebuah bentuk. Kehadiran penari memiliki peranan atau tugas masing-masing yang saling terkait sehingga kesadaran dan kemampuan individu maupun kelompok harus dibangun terlebih dahulu. Bisa dikatakan harus saling mulat, dan momong.

Ketertarikan terhadap seni tari membuat penulis ingin berperan langsung dalam melakukan riset ketubuhan yang diharap bisa mendapatkan data-data guna menyelesaikan permasalahanpermasalahan dalam ketubuhan seorang penari. Mampu menghafal belum tentu mampu menarikan dengan baik, karena hafalan hanya mengandalkan daya ingat sedangkan menari yang baik selain hafalan diluar kepala juga dituntut mampu menarikan dengan rasa sehingga melalui tari yang dibawakan penonton dapat turut merasakan suasana yang ingin disampaikan dalam tarian.

Penulis memilih tari Srimpi Ludiramadu dalam proses riset ketubuhan ini karena tari genre Bedhayal Srimpi sangat sublim atau tersamarkan secara tafsir, gerak serta suasana yang digambarkan lebih simbolis dan cenderung sulit ditangkap jika tidak ada penghayatan terhadap tarinya. Menurut Sumandiyo Hadi dalam buku "Aspek-Aspek Koreografi Kelompok" menyebutkan bahwa:

Koreografi atau komposisi kelompok dapat dianalogikan seperti pertunjukan orkes simponi terdiri dari beberapa pemain dengan instrumen sendiri-sendiri, tetapi suaranya harus padu dan harmonis (2003: 1).

Pendapat tersebut menegaskan bahwa dalam menari kelompok terdapat tingkat kesulitan yang berlebih di mana dari beberapa watak atau latar belakang penari yang berbeda harus mampu saling membentuk suatu keutuhan. Interaksi antara penari, kepekaan penari terhadap irama gending, kemampuan penari dalam menyatukan rasa, kepekaan penari akan bentuk gerak serta pola lantai, sehingga sangat dibutuhkan konsentrasi penuh dalam menarikannya. Selain itu, tari Srimpi sebagai salah satu tari yang berakar dari budaya keraton masih sangat kental akan nilai filosofisnya. Oleh sebab itu, dalam menarikannya banyak tuntutan yang harus diperhatikan.

Tari sebagai media ungkap memiliki unsur-unsur di dalamnya yaitu gerak sebagai unsur utama, serta musik, rias busana, properti, tata panggung, pencahayaan sebagai media bantunya. Bentuk sajian tari yang mendukung sangat diperlukan dalam sebuah pertunjukkan 
karena kehadirannya dapat membantu dalam menguatkan isi dari yang akan di pertunjukkan. Bentuk sajian masingmasing tarian pasti akan berbeda antara tari satu dengan yang lain. Pada tari Srimpi Ludiramadu sendiri contohnya, terdapat beberapa bentuk rias dan busananya. Pemilihan tersebut bukan semata-mata tanpa alasan, pastinya dikuatkan oleh beberapa pendapat, serta sebagai sebuah kepuasan batin tersendiri bagi seorang penari.

Berdasarkan fenomena-fenomena yang diuraikan di atas maka penulis merumuskan beberapa permasalahan antara lain: 1) Bagaimana proses kepenarian Gulu dalam tari Srimpi Ludiramadu; 2) Bagaimana garap isi dan garap bentuk tari Srimpi Ludiramadu kepenarian Gulu; dan 3) Bagaimana peran Gulu dalam tari Srimpi Ludiramadu.

\section{PROSES PENYAJIAN KARYA SENI} Tari Srimpi Ludiramadu Hasil Pemadatan

Tari Srimpi Ludiramadu merupakan tari yang lahir dari dalam tembok keraton Kasunan Surakarta. Tari ini merupakan karya cipta Kanjeng Sri Susuhunan Paku Buwono V pada tahun 1618-1748 Jawa atau 1970-1820 Masehi ketika masih menjadi putra mahkota dengan gelar Kanjeng Gusti Pangeran Adipati Anom Amengkunegara III. Tarian ini diciptakan guna mengenang ibundanya yang masih berketurunan darah Pamekasan, Madura.

Kemunculan tarian ini diawali dengan penciptaan gending Ludira. Tertulis dalam buku Serat Wedhapradangga jilid IV karya R. Ng. Pradjapangrawit sebagai berikut:
Ingkang sinuwun wau wiwit kala dereng jumeneng nata sampun kathah iyasan-iyasan utawi anggitan dalem. Langkung-langkung bab gendhing Jawi, gendhing alus, gendhing prenes, gendhing gecul. Namaning gendhing iyasan dalem wau kados ing ngandhap punika: Ludira Madura dhawah Kinanthi, pelog barang, Ranumanggala, pelog nem, Raranangis dhawah Ladrang Weling-weling, salendro nem, Montro Madura, salendro sanga, Mijil Wastrangangrang (ladrangan) gendhing kemanak, pelog barang. Pocung, salendro manyura, Gonjing Glewang, salendro manyura, Kagok Madura (ladrang), salendro sanga.

Terjemahan:

Sang sinuhun tadi sejak sebelum bertahta menjadi raja sudah banyak karya-karya atau ciptaannya. Lebihlebih tentang gending Jawa, gending alus, gending prenes, gendung gecul. Namanya gending ciptaan seperti di bawah ini: Ludira Madura dhawah Kinanthi, pelog barang, Ranumanggala, pelog nem, Raranangis dhawah Ladrang Welingweling, slendro nem, Montro Madura, slendro sanga, Mijil Wastrangangrang (ladrangan) gendhing kemanak, pelog barang. Pocung, slendro manyura, Gonjing Glewang, slendro manyura, Kagok Madura (ladrang), slendro sanga.

Secara etimologis kata Ludiramadu berasal dari dua kata yaitu "Ludira" yang berarti darah dan "Madura" yang berarti keturunan Madura, sehingga Ludiramadu 
mempunyai arti darah Madura atau keturunan dari Madura. Pada awalnya tarian ini memiliki nama Srimpi Ludiramadura. Setelah konflik perceraian tersebut dapat berakhir dengan baik dengan kembalinya Kanjeng Ratu Anom ke dalam keraton maka nama Srimpi Ludiramadura berganti menjadi Srimpi Ludiramadu. Seperti yang diungkapkan Wahyu Santoso Prabowo bahwa "Ludira" berarti darah, dan madu berarti manis sehingga Ludiramadu dapat diartikan kembalinya darah Madura yang manis (Wawancara Wahyu S. P, 2018).

Latar belakang penciptaan tari Srimpi Ludiramadu ini bermula dari perselisihan diantara kedua orang tua Adipati Anom Amangkunegaran III hingga berujung sebuah perceraian. Perselisihan Sri Susuhan Pakubuwono IV dengan Kanjeng Ratu Anom yang mengakibatkan dikembalikannya Kanjeng Ratu Anom ke pulau Madura dengan menggunakan sebuah perahu inilah yang kemudian membuat Kanjeng Adipati Anom membuat sebuah tarian guna mengenang ibundanya dan sebagai wujud kebanggannya terhadapat ibundanya yang berdarah Madura. Selain itu terdapat penggambaran kesedihan Adipati Anom ketika ibundanya dipulangkan kembali ke Madura digambarkan dengan gerakan pada bagian beksan mijil yang ditafsirkan sebagai perwujudan perahu yang terombang ambing di atas lautan lepas.

Sebelum dipadatkan secara bentuk sajian tari Srimpi Ludiramadu bisa dikatakan masih wutuh. Wutuh dalam artian di keraton pada saat sebelum memulai beksan selalu menggunakan pocapan dalang, jika di Yogyakarta disebut dengan kondho. Bentuk garap secara wutuh masih menggunakan konsep kiblat papat lima pancer, meliputi struktur beksan merong dan beksan inggah yang diulang sebanyak empat kali dengan arah hadap yang berbeda mengikuti empat arah penjuru mata angin. Pada bagian sirep dilakukan bergantian sebanyak dua kali, sehingga seluruh penari memiliki peran yang kuat.

Kemudian pada tahun 1977 tari Srimpi Ludiramadu dipadatkan oleh Agus Tasman menjadi 18 menit. Pemadatan dilakukan karena dikhawatirkan dengan durasi pertunjukkan yang begitu lama yaitu lebih kurang 1 jam akan membuat jarak antara tarian dengan masyarakat dan jaman menjadi jauh. Konsep pemadatan pada prinsipnya adalah penggarapan seni yang didasarkan atas konsep "kemungguhan", yaitu keselarasan atau keserasian atau ketepatan kesatuan wujud antara "bentuk" lahir dan "isi" yang diungkapkan (Rustopo, 2001: 159). Pemadatan ini dilakukan tanpa mengurangi esensi dari tari Srimpi itu sendiri. Pemadatan dilakukan dengan mengurangi pengulangan sekaran-sekaran yang disesuaikan dengan garap gending, menggarap kembali irama gending, dan tentunya berpengaruh terhadap perubahan pola lantai serta durasi pementasan. Pemadatan ini bertujuan agar banyak yang kemudian mempelajari tari tersebut serta tari Srimpi Ludiramadu dapat kembali akrab dengan masyarakat.

Tari Srimpi Ludiramadu merupakan bentuk koreografi kelompok yang ditarikan oleh empat penari putri dengan busana yang sama, gerak sama, dan yang memiliki gandar sama. Jumlah empat pada tari Srimpi tersebut merupakan simbol makrokosmos unsur di jagad raya yang terdiri dari, grama (api), angin (udara), toya 
(air), dan bumi (tanah). Kemudian pada masa Islam mulai masuk ke Indonesia terjadilah sebuah peristiwa local genius yang mana ajaran Islam di masukan ke dalam tari itu karena konsepnya hampir sama dengan konsep Jawa kiblat papar lima pancer bahwa manusia memiliki empat nafsu dalam diri setiap manusia.

Local genius ialah suatu kemampuan budaya dari bangsa atau masyarakat (dalam konteks ini Indonesia), dalam menerima pengaruh kebudayaan asing kemudian mengadaptasi, menggarap, dan tau mereaksi terhadap kebudayaan asing itu, sehingga muncul kebudayaan baru yang mempunyai karakterisitik atau ciri tertentu (Toto Sudarto, 2005).

Pada umumnya tema tari Srimpi adalah keprajuritan namun karena bentuk garap tarinya yang begitu simbolis dan ditafsir secara sublim maka kesan visual keprajuritan hampir tidak nampak. Namun juga terdapat beberapa Srimpi yang nampak secara visual seperti pada tari Srimpi Sangupati yang nampak dari properti yang digunakan yaitu pistol. Sedangkan pada tari Srimpi Ludiramadu lebih bertemakan percintaan.

\section{KEPENARIAN \\ GULU \\ LUDIRAMADU}

Penari gulu merupakan penari yang posisinya berada di belakang penari batak pada saat gawang urut kacang bagian maju beksan. Ketika menjadi gawang beksan pada Srimpi Ludiramadu penari gulu berada di sebelah kiri sejajar dengan penari batak. Menarikan gulu atau jangga sebagai perwujudan leher memiliki peran yang sangat penting. Kehadiran gulu sebagai leher ini menghubungkan antara batak atau kepala dengan dhadha dan buncit.
Contohnya pada saat kapang-kapang maju beksan ketika impur pertama terdapat perbedaan langkah kaki sebelum dan sesudah impur, yang mana ketika sebelum impur langkahnya masih tegas ketika sudah impur langkahnya akan sedikit diperlambat, jika langkah kaki penari gulu tidak bisa menyesuaikan maka penari di belakangnya akan sulit untuk menyamakan langkah. Pada saat tertentu penari gulu dalam tari Srimpi Ludiramadu bisa sebagai poros. Proses kepenarian ditempuh selama satu semester dibagi menjadi dua tahap yaitu tahap pemantapan dan tahap kerja kreatif.

\section{Tahap Pemantapan}

Tahap pemantapan kekaryaan adalah tahap mempersiapkan segala perlengkapan, tindakan atau rancangan yang perlu dilakukan dalam proses mencapai kualitas kepenarian yang baik. Adapun yang dilakukan pada tahap pemantapan ini adalah mengumpulkan beberapa referensi baik pustaka maupun audio visual sebanyak-banyaknya sebagai pembanding dan referensi memperkaya tehnik gerak serta melakukan wawancara sebagai pijakan menginterpretasi tarian sebagai upaya memotivasi dalam melakukan pendalaman dan pemahaman gerak.

Persiapan tehnik gerak dan mematangkan ketubuhan dilakukan, guna menambah keberagaman tehnik, mengolah, dan membiasakan tubuh bergerak sehingga nantinya tubuh akan cerdas serta sudah terbiasa dengan tehnik apapun. Penari sebagai instumen yang memainkan dapat dikatakan memiliki bobot dan kualitas apabila dapat mencurahkan seluruh ekspresi dengan 
kemantapan. Kemampuan penari dalam memahami dan menguasai beragam bentuk gerak juga akan memunculkan kemantapan dalam menarikan. Oleh sebab itu, kemampuan mempertahankan ketahanan fisik diperlukan demi mencapai kemantapan tersebut.

Pemantapan ketubuhan ini dilakukan dengan pendalaman materi tari Bedhaya Ela-Ela yang berdurasi 22 menit, dilakukan lebih kurang selama 2 bulan. Materi tari Bedhaya Ela-Ela ini dirasa mampu mengolah ketubuhan baik tehnik, bentuk dan juga rasa. Jika sudah mampu menguasai rasa maka dengan sendirinya tubuh akan berbicara. Pada tahap pemantapan ketubuhan selain menggunakan materi tari Bedhaya Ela-Ela juga menggunakan materi tari Gambyong Pareanom. Tarian ini akan tersampaikan kesan centilnya jika penari mampu njogedi gending dalam artian penari bergerak mengikuti irama musik. Pada tahap ini penari dituntut mampu melakukan gerakan srisig dengan tehnik yang baik dan benar, yaitu kecil-kecil, badan ngunci, dan cepat tapi tidak kemrungsung (tergesagesa). Oleh sebab itu kekuatan tungkai kaki sangat diperlukan dalam mencapai kualitas srisig yang baik. Setelah pemantapan ketubuhan dirasa cukup kemudian masuk tahap selanjutnya yaitu kerja kreatif yang menuntut mahasiswa untuk menyajikan tarian sesuai dengan interpertasi masing-masing.

\section{Tahap Kerja Kreatif}

Pada tahap kerja kreatif inilah dipilih materi Srimpi Ludiramadu. Selain belum pernah digunakan sebagai materi pembelajaran ketertarikan muncul dari bentuk gerak tarinya dengan menggunakan pola lantai yang sedikit berbeda dari tari Srimpi lainnya. Selain itu, materi ini masih jarang dipertunjukan. Hal inilah yang mendorong munculnya ketertarikan dan dipilihlah materi tari Srimpi Ludiramadu sebagai penari gulu. Tahap kerja kreatif ini ditempuh selama tiga bulan.

Upaya pencapaian kualitas kepenarian yang dilakukan guna menghasilkan karya yang orisinil menggunakan riset analisis dan proses dengan mentafsirkan bentuk dan isi tari Srimpi Ludiramadu. Ketepatan gerak dan kemungguhan rasa yang ingin dicapai perlu didukung oleh ketrampilan, interpretasi, dan kreativitas yang dapat mengarah pada penghayatan dan penjiwaan tari (Widyastutieningrum, 2012: 38). Kegiatan riset ini dilakukan menggunakan beberapa kepustakaan, dengan mengumpulkan data-data tertulis guna mengetahui latar belakang penciptaan tari Srimpi Ludiramadu. Serta beberapa diskografi sebagai referensi dalam pencarian tehnik dan pencapaian rasa yang diinginkan.

Proses kreatif kepenarian gulu dilakukan dengan beberapa tahapan. Tahap pertama yang dilakukan adalah eksplorasi pencarian bentuk gerak sekaran dan tehnik pada tari Srimpi Ludiramadu. Pada proses pendalaman dan pemahaman gerak dilakukan bertahap, secara terstuktur. Diawali pada proses maju beksan, kemudian beksan, dan terakhir mundur beksan. Secara keseluruhan tahap pencarian bentuk ini berfokus pada pencapaian tehnik baik lintasan gerak maupun adeg. Tujuan dilakukan pencarian ini selain mencari tehnik secara luwes, patut, dan resik diharap penari gulu dapat memunculkan rasa yang sama dengan 
melakukan tehnik yang seragam dengan keseluruhan penari.

Pada tahap pencarian ini perlu adanya latihan yang intensif dan continue yang bertujuan untuk menghasilkan kualitas penari yang baik. Pembenahan dan masukan dari dosen digunakan sebagai acuan gerak. Pada dasarnya tubuh bergerak secara maksimal dengan tehnik leyekan serta tolehan yang dimaksimalkan. Sehingga tubuh tidak mati, dan tubuh tidak terpaku di tengah karena konsep menari dalam tari Jawa adalah mucang kanginan (pohon pinang yang tertiup angin).

Kedisiplinan sangat diperlukan dalam hal ini, di mana setiap penari memiliki tanggung jawab terhadap dirinya sendiri dan penari lain (mulat) supaya tercipta suatu komunikasi atau interaksi yang baik antar penari, sehingga tidak menari sendiri-sendiri. Kesadaran terhadap bentuk sangat diperlukan karena jika tidak dibiasakan terkadang posisi badan terlebih bahu masih diberi tekanan sehingga terlihat kaku. Polatan masih sering plirak-plirik, ndisiki (tidak fokus). Hal itu juga sering dialami dalam latihanlatihan awal. Pada tahap eksplorasi yang dilakukan ditemukan tehnik leyekan yang maksimal dengan mengurangi gerak gejug samparan, setiap srisig diakhiri mancat kanan. Selain itu, tehnik peralihan dari sekaran adu manis menjadi sekar suwun menemukan sebuah tehnik memindah kaki setelah gejug agar diperoleh leyekan yang maksimal dan kain samparan tidak nyrimpet.

Tahap kedua adalah mendengarkan gending tari. Pada tahap ini musik dimainkan berulang-ulang supaya antara penari, gerak, dan musik dapat menjadi satu kesatuan. Pada tahap ini lebih fokus pada pencarian seleh gending diikuti dengan melakukan gerakan-gerakan kecil sehingga bisa merasakan aliran tubuh yang bergerak sesuai irama gending. Perlakuan ini juga dilakukan berulangulang, selain menggunakan musik mp3, juga menggunakan musik gamelan langsung sehingga bisa merasakan peralihan gending. Kemudian masuk pada proses dengan instrumen musik gamelan langsung, lebih difokuskan pada pencarian seleh-seleh gending yang diselaraskan dengan seleh gerak dengan langkah mendengarkan gending secara berulangulang. Hal ini diperlukan agar setiap gerak dan gending beksan bisa memunculkan rasa yang satu. Kehadiran musik di sini bukan hanya sebagai pelengkap tetapi juga berperan sebagai penguat suasana tari.

Tahap ketiga adalah eksplorasi pencapaian lintasan gerak. Pada tahap ini berfokus pada pencarian perpindahan lintasan yang berhubungan dengan pola lantai serta tehnik mengawali dan mengakhiri gerakan. Pola lantai yang terdapat pada tari Srimpi Ludiramadu banyak menggunakan pola simetris sehingga keseimbangan sangat diperlukan. Pencapaian posisi dan peralihan harus dilakukan secara bersamaan maka tehnik yang digunakan pun harus diperhitungkan. Hitungan memulai perpindahan selalu sama namun hitungan ketika berpindah tidak harus sama. Hal ini dikarenakan jarak posisi yang akan dituju setiap penari belum tentu sama, sehingga harus saling ngemong budal bareng teko bareng (berangkat bersama, sampai bersama).

Selama proses berlangsung terdapat beberapa hambatan yang dirasakan perlu 
adanya peningkatan. Setiap penari dalam tari Srimpi Ludiramadu ini memiliki peran penting. Begitu pula penari Gulu yang memiliki peran sebagai poros dalam pencapaian posisi gerak dan sebagai poros dalam beberapa peralihan gerak. Misalnya dalam sekaran laras, dan sembahan laras, Gulu selalu sebagai acuan bergerak karena posisinya berada di pojok kiri depan. Pada sekaran tersebut gerak nekuk kenceng lengan dilakukan dengan tolehan menghadap ke kiri, sehingga penari Gulu di sini sebagai patokan. Pada peralihan srisig untuk mencapai perpindahan gawang penari Gulu berperan menentukan posisi gawang.

Detail-detail kecil dalam menari seperti gerak dagu yang harus luwes, peralihan gawang yang tidak terlalu lebar serta kualitas penari dalam mempertahankan intensitas irama dan tenaga sangat perlu diperhatikan. Bentukbentuk detail gerak seperti posisi jengkeng, lebar kecilnya lintasan gerak, proses mengawali dan mengakhiri setiap gerak dalam menari kelompok sangat diperhatikan guna menghasilkan rasa yang sama antar penari. Kemampuan kepenarian yang selama ini dipelajari dirasa masih belum mampu menghasilkan kepenarian yang dinilai baik. Masih perlu adanya pembenahan serta kesadaran pribadi dalam bergerak. Pandangan mata yang masih kosong dan kurang meneb. Polatan mata yang masih sering terlihat melamun memunculkan rasa yang berbeda dengan pendukung sajian yang lain.

Setelah melalui proses latihan mandiri dengan beberapa kali bimbingan dan pembenahan untuk mencari detail gerak untuk menyamakan rasa keempat penari didapatkan hasil bahwa kemampuan kepenarian cukup bagus, kemampuan dalam kelompok bisa mendukung materi Srimpi Ludiramadu sebagai penari Gulu. Belajar mengendalikan ego sangat diperlukan agar mampu membangun rasa yang sama. Gandar penari yang kecil dipertimbangkan ketika pemilihan bentuk gerak seperti tanjak tidak terlalu rendah, dan leyekan, tolehan dimaksimalkan agar lebih terlihat dari kejauhan. Setelah melalui proses penggarapan tanggal 19 Desember 2018 malam diadakan penyajian materi tari Srimpi Ludiramadu di gedung Teater Besar ISI Surakarta dengan garap isi mrabu, kenes, dan meneb.

\section{Tahap Penggarapan}

Proses penggarapan ini didasari dengan konsep tradisi tari Jawa yang dicetuskan oleh Suryodiningrat yaitu konsep Hasta Sawanda yang terdapat pada buku "Revitalisasi Tari Gaya Surakarta" oleh Sri Rochana Widyastutieningrum tahun 2012. Konsep Hasta Sawanda ialah sebuah konsep dasar tari jawa yang terdiri dari delapan unsur meliputi pacak, pancat, ulat, lulut, wiled, luwes, irama dan gendhing.

\section{Pacak}

Pacak adalah keseluruhan ekspresi gerak yang dibuat bagus dan sesuai dengan setiap tarian tertentu. Pacak dalam setiap tarian yang berbeda tidak akan sama walaupun dibawakan oleh satu penari. Penggarapan pacak lebih pada interpretasi masing-masing penari yang kemudian disamakan melalui detail gerak-gerak kecil. Pada penyajian Srimpi ini secara pacak tidak dibuat-buat seperti bentuk adeg ketika jalan kapang-kapang tidak terlalu kaku, badan tidak terlalu mayuk 
kedepan. Posisi kaki ketika berjalan mager timun, tubuh ngunci, dan posisi tangan semeleh. Posisi dan gerak leher yang luwes sehingga akan lebih memunculkan rasa dari dalam atau tan wadhag.

\section{Pancat}

Pancat adalah pola kesinambungan atau tehnik mengawali dan mengakhiri setiap sekaran tidak terasa terpisah. Setiap pergantian gerak yang dilakukan harus serasi dan menyatu. Pancat dapat dilakukan dengan perpatokan pada hitungan atau mengikuti setiap seleh gending misal midak, nujah, nggandul, dan nranjal.

Pada penyajian ini digarap secara midak atau bisa dikatakan menggunakan hitungan pas antara gerak dengan jatuhnya gong seperti contohnya pada gerak lembehan wutuh, dan nggandul atau beberapa hitungan setelah gong yang diselaraskan dengan seleh irama gending serta sindenan. Beberapa hitungan dibuat nggandul 1 sampai 2 hitungan. Selain itu, penerapan tehnik samparan serta tumpuan kaki dalam mengawali dan mengakhiri gerak seperti pada gerak madal pang srisig kemudian ketika sampai mancat digarap dengan mengurangi gerak gejug dan lebih memaksimalkan leyekan.

\section{Ulat}

Ulat adalah sikap pandangan mata atau polatan dan ekspresi wajah sesuai dengan karakter tari yang dibawakan sebagai upaya mencapai pesan dramatik yang ingin disampaikan. Pola ulatan dalam menari Jawa akan mengikuti setiap alur pergerakan ujung jari. Kualitas tari putri dapat dikelompokan menjadi dua yaitu putri lanyap (branyak atau endel) dan putri luruh (oyi). Tari dengan genre Srimpi memiliki karakter tari putri luruh atau oyi yang volume gerak atau ruang geraknya kecil dengan polatan sedikit menunduk, tidak lurus kedepan. Polatan atau ekspresi wajah para penari Srimpi tidak ditunjukan secara wadag. Polatan pada tari Srimpi lebih dibangun dari dalam tubuh penari (rasa), sehingga polatannya cenderung tenang dan halus. Arah pandangan mata para penari juga tidak memandang lurus jauh kedepan, melainkan sedikit memandang sejauh kurang lebih atau sedikit menunduk dibandingkan dengan karakter gerak lanyap (branyak). Kurang lebih arah polatan sejauh arah pentangan ujung jari atau sedikit diatas ujung jari.

Secara tehnik tolehan pada tari Srimpi bisa digarap dengan tolehan yang tidak maksimal atau membentuk sudut sejajar dengan arah pentangan tangan. Ada pula yang digarap secara maksimal. Sedangkan untuk arah tolehan pada penggarapan Srimpi ini digarap lebih dimaksimalkan agar terlihat lebih sigrak dan arah tolehannya diharapkan akan sama. Selain itu, dengan tolehan yang dilakukan secara maksimal akan menjadikan fokus arah pandangan pada satu titik serta dapat digunakan sebagai cara menyesuaikan setiap gerak dengan antar penari.

\section{Lulut}

Lulut adalah ketepatan dalam penempatan tehnik gerak sehingga tubuh yang bergerak dapat mewadahi ide estetik. Maka akan muncul esensi tari yang dibawakan bukan figure dari penari yang membawakan. Kemampuan penari dalam memilih tehnik gerak yang sesuai dengan tari yang dibawakan sangat diperlukan. 
Keselarasan gerak dengan musik tarinya akan mampu menghasilkan sebuah keutuhan dalam tari. Keutuhan gerak, gending, dan rasa bisa dikatakan lulut apabila sudah nyawiji secara rasa tidak terkotak-kotak.

\section{Wiled}

Wiled adalah tehnik gerak kreatif seorang penari secara khusus atau ciri khas yang dimiliki penari, sehingga dapat dikatakan wiled merupakan ciri khas gaya setiap penari. Wiled seorang penari pastinya akan berbeda-beda. Wiled hadir dari interpretasi penari akan gerak yang ada dengan kemampuan ungkap dari masing-masing penari. Bisa dikatakan setiap gerak yang dimunculkan secara bentuk bisa sama tetapi secara proses menuju bentuk tersebut terdapat aksenaksen tertentu yang muncul dari daya tangkap sang penari. Pencapaian wiled seorang penari akan sulit dituliskan menjadi sebuah kalimat karena wiled lebih pada ciri khas dalam bergerak.

\section{Luwes}

Penari dikatakan luwes apabila keseluruhan gerak yang dilakukan apapun bentuk geraknya enak dilihat dalam arti kualitas geraknya. Luwes dapat dipengaruhi faktor kemampuan atau bakat yang sudah dimiliki.
Pemilihan tehnik-tehnik gerak yang digunakan juga mempengaruhi keluwesan yang ingin dimunculkan. Tehnik gerak pada Srimpi Ludiramadu ini disesuaikan dengan gandar dari masing-masing penari agar terlihat lebih luwes dan patut. Penggunaan tehnik seperti tanjak tidak terlalu rendah dikarena postur penari yang kecil agar tidak terlihat semakin kecil, namun lebih menekankan pada tehnik leyekan, serta proses pengawali dan mengakhiri setiap gerak. Pemilihan tehniktehnik kecil dari ujung kepala hingga kaki lebih didetailkan agar dapat memunculkan satu rasa yang sama dari keempat penari.

\section{Irama}

Irama dalam konsep Hasta Sawanda lebih merupakan konsep penggunaan musik tari sebagai media bantu mewujudkan alur garap tari secara utuh menjadi suatu harmoni rasa tertentu dan satu kesatuan. Irama dapat disebut juga dengan laya atau tempo. Ketika menari, penari harus mampu mengikuti irama artinya tidak boleh kemrungsung ataupun ketinggalan. Pada proses penyajian ini kemampuan dalam irama dilatih dengan mendengarkan dan mencari seleh sindenan. Contohnya diuraikan pada bagian sindenan, notasi serta gerak beksan mijil. 
Buka celuk:

$\begin{array}{lllllllllll}\text { - } & 3 & 5 & 6 & 7 & 7 & 7 & 7 & 2 & 6 & 7\end{array}$

$\begin{array}{llllllllllll}3 & 5 & 6 & 7 & 7 & 7 & \overline{7 \dot{2}} & 7 & \overline{6} & 6 & \overline{7 \dot{2}} & \dot{2}\end{array}$

Was-tra ngang-rang te- beng- ing pa - ta - ni

Jengkeng - lenggut..............

. . $2 \dot{3} 2756$

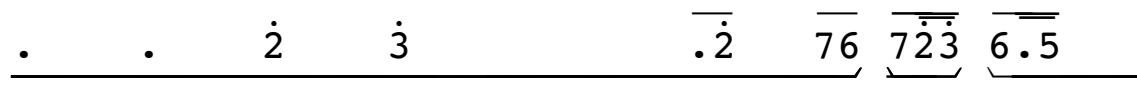

pang - ga sembahan udar. gedheg

335 p6 353 n2

$3 \cdot \underbrace{3 \overline{56}} \begin{array}{llll}6 & \overline{\overline{67}} & 5 & \overline{653} \\ 72\end{array}$

gas - ing ba - tos

seleh kiri ..... kapyuk kanan menthang kiri.. seblak kanan jatuh pada seleh sindenan

Uraian di atas memperlihatkan bahwa seleh gerak. Setiap gerak dilakukan mengikuti alur tarikan nafas seorang sinden.

\section{Gendhing}

Pada konsep Hasta Sawanda yang dimaksud dengan gendhing adalah suatu konsep penguasaan musik tari untuk membangun interpretasi terhadap gerak dengan cara mentafsir rasa gending. Pada tari Srimpi Ludiramadu ini menggunakan gending beksan pathetan ageng laras pelog pathet barang, Ludiramadu kethuk 4 kerep, kinathi kethuk sekawan, pathetan jugak, ladrang mijil ludira, dan ladrang Singa-Singa yang memunculkan rasa nyawiji antara gerak dan gending.

Penggarapan yang berpijak pada konsep Hasta Sawanda ini diharapkan mampu menghasilkan kepenarian yang baik serta karakterisitik tersendiri dalam ketubuhan masing-masing penari.

\section{MAKNA SIMBOLIS PERAN GULU}

Kebudayaan Jawa mengenal konsep mikrokosmos bahwa manusia sejak lahir memiliki yang dinamakan sedulur papat lima pancer yang dikemukakan oleh Pangeran Suryodinigrat. Sedulur papat lima pancer ini terdiri dari kakang kawah, adi ariari, getih abang, dan getih putih. Sedangkan, pancernya ialah si jabang bayi atau manusia itu sendiri.

Ketika Islam masuk keempat unsur tersebut merupakan simbol mikrokosmos kehidupan yang ditandai dengan empat nafsu manusia yang terdiri dari nafsu amarah, nafsu aluamah (rakus), nafsu supiyah (seks), dan nafsu mutmainnah (tenang).

Nafsu Amarah : yaitu nafsu manusia yang selalu merasa ingin menang sendiri.

Nafsu Aluamah: yaitu nafsu manusia yang rakus atau serakah merasa ingin memiliki segalanya.

Nafsu Supiyah: yaitu nafsu manusia yang umumnya memiliki sifat senang akan keindahan, kemewahan misalnya wanita. 
Nafsu Mutmainnah: yaitu nafsu manusia yang sudah tenang, tentram dan selamat jauh dari sifat tercela.

Semuanya dilambangkan dalam peran masing-masing penari yaitu:

\section{Batak}

Penari batak merupakan perwujudan dari pikiran dan jiwa manusia yang disimbolkan sebagai kepala. Peran penari batak di sini adalah sebagai yang memimpin atau yang mengendalikan. Perwujudan batak jika dikaitkan dengan keempat nafsu manusia dapat dikaitkan dengan nafsu mutmainah yang mana seorang pemimpin harus senantiasa membawa anggotanya dalam hal yang positif, membawa ketenangan serta mampu mengkoordinasi anggotanya.

\section{Gulu}

Penari gulu atau jangga merupakan perwujudan dari nafsu aluamah atau nafsu serakah yang dimiliki oleh manusia yang disimbolkan sebagai leher. Secara metafora manusia makan, minum dengan mulut dan masuk ke perut melalui leher. Nafsu untuk terus ingin memiliki sesuatu walaupun itu bukan milikinya, melakukan kegiatan secara berlebihan.

\section{Dhadha}

Penari dhadha merupakan perwujudan dari bagian tubuh manusia yaitu dada yang dapat dikaitkan dengan nafsu amarah seorang manusia. Emosi atau amarah seorang manusia secara simbol dapat dirasakan di dada oleh sebab itu ada istilah jawa dada muntab atau sebuah kemarahan yang sudah berlebih dan tidak bisa ditahan lagi untuk diungkapkan.

\section{Buncit}

Penari buncit merupakan perwujudan dari bagian organ seks yang dapat dikaitkan dengan nafsu supiyah atau nafsu manusia yang selalu menginginkan keindahan. Misalnya berganti-ganti pasangan, keinginan akan hal keindahan yang bersifat duniawi. Sedangkan pancernya adalah nafsu mulhimah. (Prabowo, 2007: 23). Namun untuk pancernya tidak semua dinampakkan, terkadang pancernya bersifat imajiner. Namun juga ada ada yang dinampakkan, contohnya pada tari Srimpi Jayaningsih. Nafsu mulhimah yaitu nafsu yang selalu mendapat ilham supaya berbuat menunaikan kebaikan (Syaban, dalam 7 nafsu manusia).

Penari Srimpi memiliki peran masing-masing yang mana kehadirannya saling menguatkan satu sama lain. Peran penari Srimpi selain disimbolkan sebagai mikrokosmos kehidupan juga merupakan simbol dari makrokosmos kehidupan atau unsur alam semesta yang ada meliputi elemen api, air, angin, dan tanah. Keempat elemen tersebut sangatlah penting bagi kebutuhan hidup manusia. Elemenelemen tersebut kehadirannya saling mempengaruhi keseimbangan di alam semesta dan saling membutuhan. Keempat elemen tersebut memiliki karakteristik dan kegunaan yang berbeda-beda.

Beberapa ilmu filosofi yang membahas mengenai kehidupan manusia menyebutkan bahwa setiap manusia memiliki unsur keseimbangan dalam tubuh. Sebuah filosofi Tionghoa menyebutkan konsep Yin dan Yang untuk mendeskripsikan sifat kekuatan yang saling mempengaruhi dan berlawanan. Setiap tubuh manusia dipercaya memiliki 
unsur Yin dan Yang tersebut. Pada ilmu filosofi Jepang juga menyebutkan bahwa dalam tubuh manusia memiliki unsur seperti api, air, udara, dan angin.

Jika dikaitkan dengan peran masing-masing penari sebagai berikut, penari Batak dapat disimbolkan sebagai elemen air. Pada kehidupan sehari-hari air sangat berguna dalam membantu memenuhi kebutuhan aktivitas manusia, seperti minum, mandi, dan mencuci. Air memiliki spektrum warna biru. Air memiliki sifat cair yang dapat menyesuaikan di dalam bentuk wadah apapun. Unsur yang balik banyak terkandung dalam tubuh manusia adalah air. Air memiliki sifat yang tenang, menyejukan, fleksibel, dan kesabaran. Sama halnya dengan penari Batak yang merupakan seorang kepala atau ketua dalam kelompok yang senantiasa harus mampu memberikan ketenangan serta mengayomi para anggotanya agar mampu berjalan beriringan dengan sebuah pemikiran yang sama. Elemen air memiliki kelemahan yaitu udara.

Gulu merupakan simbol dari elemen tanah yang mana memiliki sifat yang kokoh, keras. Ketika mengambil suatu tindakan memiliki ketegasan, sabar, dan tenang. Bumi atau tanah merupakan tempat manusia tinggal atau berpijak. Elemen ini memiliki kelemahan yaitu air. Seorang penari Gulu dalam menari harus memiliki prinsip karena berperan sebagai acuan bergerak. Selain itu, lintasan gerak yang lebih sempit dari penari lainnya membuat penari Gulu harus mampu mengolah sabar serta ketenangan dalam nyemelehke rasa agar nantinya sama dan tidak mendahului.
Dhadha dapat disimbolkan sebagai elemen api. Umumnya api memiliki sifat panas, yang memiliki unsur warna merah, api dalam kehidupan sehari-hari dapat digunakan untuk membakar. Pada tubuh manusia api dapat dilambangkan sebagai amarah, atau emosi yang membara. Kelemahan api adalah air.

Buncit dapat disimbolkan sebagai elemen angin. Elemen angin saling berkaitan dengan elemen udara karena elemen angin merupakan serapan dari elemen udara. Angin dalam kehidupan di alam semesta memiliki peranan sebagai media respirasi udara. Angin atau udara memiliki sifat yang selalu berubah-ubah atau tidak konsisten. Angin memiliki kelemahan yaitu elemen api.

Setiap elemen memiliki kelebihan dan kelemahan masing-masing yang saling berhubungan. Oleh sebab itu, masing-masing penari tidak bisa dikatakan menari Srimpi apabila hanya menari sendiri tanpa adanya suatu keseimbangan atau keselarasan rasa.

Elemen makrokosmos di alam semesta tidak hanya meliputi api, air, angin, dan tanah. Elemen lainnya adalah keempat penjuru arah mata angin yaitu, Utara, Selatan, Barat, dan Timur. Makna simbolis peran penari Srimpi juga dapat dilihat dari elemen tersebut sebagai berikut,

Utara merupakan arah mata angin pertama yang digunakan sebagai acuan penentuan arah mata angin lainnya dalam kompas, sehingga dapat dikatakan bahwa utara merupakan simbol dari penari Batak. Selatan memiliki unsur warna merah yang secara simbolis merupakan simbol penari Dhadha. Arah barat merupakan unsur elemen logam atau udara. Arah barat 
merupakan arah tenggelamnya matahari. Arah barat merupakan simbol dari penari Buncit. Terakhir adalah arah mata angin timur. Timur merupakan arah terbitnya matahari, yang memiliki makna memunculkan sebuah harapan baru. Timur memiliki unsur tanah atau tempat bumi dipijak. Secara filosofi arah timur merupakan simbolis dari penari Gulu.

\section{PENUTUP}

Srimpi adalah salah satu genre tari tradisi keraton berpola kelompok yang memiliki kualitas gerak putri luruh atau oyi. Tari Srimpi Ludiramadu dipilih sebagai media riset ketubuhan karena dianggap mampu meningkatkan kualitas ketubuhan melalui riset mandiri yang mana kemampuan kepenarian secara individu serta secara kelompok benar-benar diperlukan guna membangun interaksi dalam sebuah kelompok dengan memunculkan rasa tari yang sama. Adapun tahap yang dilakukan dalam proses kerja kreatif ini berpijak pada konsep dasar tari Jawa yaitu Hasta Sawanda guna mencapai kualitas kepenarian yang bisa dikatakan mumpuni.

Tahapan proses dalam mencapai kualitas kepenarian yang baik tidak mampu hanya ditempuh dalam waktu yang singkat. Latihan secara berulangulang dan dalam jangka waktu yang cukup lama belum tentu mampu menghasilkan kepenarian yang baik apabila tidak didasari dengan kesadaran tubuh dalam bergerak serta pemahaman akan latar belakang tari sebagai sebuah motivasi dalam melakukan setiap gerak.

Peran masing-masing penari dalam tari kelompok seperti Srimpi sangat penting. Setiap penari harus mampu membangun interaksi serta saling bertanggung jawab antara satu dengan lainnya. Seperti halnya peran gulu dalam tari Srimpi Ludiramadu. Gulu merupakan perwujudan dari jangga atau leher yang bisa diartikan sebagai simbol keserakahan yang dimiliki oleh manusia. Kehadiran penari gulu dalam tarian ini juga sebagai poros atau titik dalam pencapaian setiap peralihan gerak. Penari gulu tidak boleh seenaknya saja dalam bergerak, juga harus memperhatikan penari lainnya agar tetap terjaga keseimbangan pola simetrisnya.

Tari Srimpi Ludiramadu yang disajikan tidak merubah bentuk gerak yang sudah ada, pemilihan tehnik dan rias busana disesuaikan dengan gandar penari yang kecil sehingga tetap terlihat patut, dan luwes. Kepenarian gulu yang disajikan merupakan hasil interpretasi penari dengan rasa tari yang mrabu, kenes dan meneb.

\section{DAFTAR PUSTAKA}

Dewan Ahli Yayasan Siswa Among Beksa Ngayogyakarta Hadiningrat. 1981. Kawruh Joged - Mataram. Yogyakarta.

Hadi, Y. Sumandiyo. 2003. Aspek-Aspek Dasar Koreografi Kelompok. Yogyakarta: eLKAPHI.

Hawkins, Alma M. 1990. Mencipta Lewat Tari "Creating Through Dance", dialihbahasakan oleh Y. Sumandiyo Hadi. Yogyakarta: Institut Seni Indonesia.

Langer, Suzanne K. 1988. Problematika Seni. Dialih bahasakan oleh FX. 


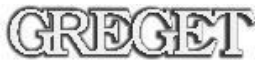

Widaryanto. Bandung: Akademi Seni Tari.

Maryani, Dwi. 2007. “Wiraga Wirama Wirasa Dalam Tari Tradisi Gaya Surakarta," Gelar, Jurnal Ilmu dan Seni ISI Surakarta Volume 5 No. 1 (Juli 2007): 28-41.

Murgiyanto, Sal. 1992. Koreografi. Jakarta: Pusat Perbukuan Depdikbud.

Prabowo, Wahyu Santoso, dkk. 2007. Sejarah Tari Jejak Langkah Tari Di Pura Mangkunegaran. Surakarta: ISI Surakarta dan CV Efek Design.

Pradjapangrawit, R. Ng. 1990. Serat Sujarah Utawi Riwayating Gamelan Wedhapradangga (Serat Saking Gotek). Alih aksara oleh Sogi Sukidjo, R. Ng. Renggosuhono. Surakarta: STSI Surakarta bekerja sama dengan The Ford Foundation, Jakarta.

Rustopo. 2001. Gendhon Humardani Sang Gladiator. Yogyakarta: Yayasan Mahavhira.

Wahyudi, Didik Bambang, dkk. 1997. “Tari Srimpi Jayaningsih (Tinjauan tentang Garap Bentuk Sajian)," Laporan Penulisan Kelompok, Sekolah Tinggi Seni Indonesia, Surakarta.

Widyastutieningrum, Sri Rochana. 2012.

Revitalisai Tari Gaya Surakarta. Surakarta: ISI Press Solo.
Narasumber

Dwi Rahmani (56 tahun), dosen Tari Gaya Surakarta Putri, Surakarta.

Rusini (70 tahun), penari senior, Surakarta.

Wahyu Santoso Prabowo (65 tahun), penari senior, Surakarta.

Nanuk Rahayu (62 tahun), dosen tari Surakarta Putri, Surakarta.

Didik Bambang Wahyudi (59 tahun) dosen tari, Surakarta. 